\title{
Water Availability, Quality And Treatment Methods In Malawi: A Review
}

\author{
Mumba Mercy ${ }^{1}$, Kilingo Flory Mkangombe ${ }^{2}$ and Prof. Zhang Yongji ${ }^{3}$ \\ ${ }^{1}$ UNEP-TONGJI Institute of Environmental Sciences and Sustainable Development (IESD) Tongji University, Shanghai, China. 200092. \\ ${ }^{2}$ UNEP-TONGJI Institute of Environmental Sciences and Sustainable Development (IESD) Tongji University, Shanghai, China. 200092.
}

DOI: 10.29322/IJSRP.11.06.2021.p11472

http://dx.doi.org/10.29322/IJSRP.11.06.2021.p11472

\begin{abstract}
Water is essential in all aspects of life such as health, economic growth, food production and support for the environment. Water is scarce mainly in developing countries and pollution of the water resources is a major challenge contributed by the discharge of wastewater from industries and municipal, agriculture runoff, household wastes and others. The mainly used water resources in African countries are Lakes, boreholes, rivers, shallow wells, streams and springs. People consume water from unprotected sources without treatment leading to an outbreak of waterborne diseases. The water resources recorded high pollution levels with contaminants concentrations above the acceptable limits by the Malawi Bureau of Standards (MBS) and World Health Organization (WHO) for drinking water. Parameters such as turbidity, Faecal coliforms and bacteria counts in the shallow wells for the sampled and analyzed water recorded a high-value range above the permissible limits for drinking water. The drinking water treatment methods used are disinfection, filtration and boiling by a large percentage of pollution at the household level. Total dissolved solids, electrical conductivity and nitrates in the analysis done for the water from the wells and boreholes were within the allowable for drinking water standards. The TSS in another study analyzed for the drinking water recorded value above the WHO and MBS standards caused by the direct discharge of the wastewater to water bodies. The water treatment plants treat surface water and groundwater recorded raw water quality of some of the parameters within the allowable limits with and exemption of Liwonde water treatment plant recorded high turbidity water above drinking water standards. Water treatment plants also recorded better removal of the pollutants in the water through coagulation, flocculation, sedimentation, filtration and disinfection processes. The water quality index (WQI) as a key method for regulating water quality for domestic use and the overall effects of quality of water parameters that pose risk to water usage. The WQI provides valuable information to water resource managers for it is efficiently reliable and useful method for communicating and evaluating the overall quality water information. In terms of total hardness, the water quality was rated as mild hard to very hard water, while in salinity the water recorded high concentration of total dissolved solids and electric conductivity. Therefore, this review paper, determined the water resources, water quality, and the treatment techniques for the drinking water, hence a cost-effective, feasible and affordable water treatment method is suggested for the water treatment plant in the treatment of the drinking water.
\end{abstract}

Index Terms- Drinking water, Water resources, Water treatment, Water Quality Index, Drinking water standards

\section{INTRODUCTION}

$\mathrm{T}$ he earth's surface is covered by water to about 70\% according to (Ngoma, Hoko et al. 2020), though still, the water remains to be a challenge worldwide. Moreover, the study projected that by 2030 , about $40 \%$ of the water withdrawal and water supply will have been advanced sustainably. Water is considered an important resource that when safely and sufficiently services are available becomes vital for maintaining and protecting the health of the people and the environment (Manda, Chidya et al. 2016, Guo and Bartram 2019, Zhang, Zhang et al. 2020). Water is essential in all aspect of life such as health, economic growth, food production, and support for the environment (Björklund 2001, Tyagi, Sharma et al. 2013, Mkwate, Chidya et al. 2017), but still, about 1.1 billion people depend on unsafe drinking water sources like rivers, open wells and lakes and a population of 2.4 billion people have inadequate sanitation globally (Msilimba and Wanda 2013) and about 2 billion people global drink water from sources highly contaminated with faecal (Ward, Lapworth et al. 2020). Therefore, its availability in large quantities and good quality is greatly needed worldwide (Zhang, Zhang et al. 2020). Water scarcity is observed to be a major worldwide challenge due to fast growing population and industrialization that has led to the consumption of a large volume of clean water. Globally about $96 \%$ of the population use enhanced drinking water sources while $84 \%$ of the population with unimproved sources particularly in rural areas (Mkwate, Chidya et al. 2017). However, domestic poor water supply, quality and sanitation services are still a challenge in developing countries and public utilities provided about $90 \%$ of the sanitation services and water supply to urban areas (Kalulu and Hoko 2010). Moreover, 80\% of the illnesses are recorded in developing countries due to approximately $80 \%$ of the people having poor water and sanitation services as stated by (Björklund 2001, Pritchard, Mkandawire et al. 2008). The poor management of the water in developing countries has also resulted in water challenges for only about $18 \%$ of the residents in developing countries have good access to water supply for the household (Björklund 2001). Water pollution is another major challenge that faces most of the growing countries with poor sanitation services (Manda, Chidya et al. 2016). 
The growth of industries, agriculture and population has resulted in to discharge of the wastewater into the environment making their way to water resources such as rivers, boreholes, streams, shallow wells and others. As stated by (Björklund 2001), the population of about $90 \%$ and more discharge sewage water directly to water sources such as rivers, coastal waters, and lakes. This has led to water quality distortion resulting in a negative effect on wellbeing of residents and the environment due to inadequate water quality management or inadequate water treatment technologies in most of the third-world countries leading to consumption of the contaminated water without treatment hence the rise of cases for an outbreak of waterborne diseases such as cholera. African countries, such as Malawi particularly only about $65 \%$ of the population have adequate, safe and sustainable drinking water sources and $50 \%$ reported cases of waterborne diseases (Pritchard, Mkandawire et al. 2008). However, improving the situation in a country is a challenge due to inadequate finance and population growth in Malawi. The urban population of the country is observed to have an annual growth rate of $6.3 \%$ which is thrice the world growth rate and almost twice by $3.5 \%$ mean growth rate for Africa, this has resulted in inadequate clean water and sanitation services (Ngoma, Hoko et al. 2020). Furthermore, the available water for consumption in Malawi country is boreholes, rivers, springs, lakes, streams and shallow wells which in most cases are highly polluted by household and farming activities. As stated by (Kanyerere, Levy et al. 2012, Nyirenda, Mapoma et al. 2015), Malawi though has plentiful water but still, about $60 \%$ of the population has inadequate safe drinking water and unimproved sanitation. According to (Mkandawire and Banda 2009) about 16\% of the population uses water resources such as rivers and lakes, $37 \%$ use boreholes, $21 \%$ use piped water and $26 \%$ get their drinking water from the unprotected well (figure 2).

The little available water in the country is costly and people have to walk long distances to obtain the water. A large percentage of the population is observed to consume water from unprotected sources putting the health of the people in the region at risk of waterborne diseases. In Malawi, there is inadequate access to sufficient and safe drinking water leading to deaths and high cases of waterborne diseases recorded yearly (Kayser, Amjad et al. 2015, Manda, Chidya et al. 2016). The main cause of death is the insufficient water for personal hygiene and unsafe consumption of water highly contributed by polluted water sources. Moreover, attaining and preserving adequate water service is not easy mostly in low- and middle-income countries and in rural areas (Guo and Bartram 2019). According to (Kayser, Amjad et al. 2015) there are many technologies which have been developed to help in improving the drinking water quality, by introducing the treatment techniques but yet there is a continuous obstacle to most of the developing countries. This has been contributed to large population which has led to production of large amount of wastewater and solid wastes that finds their way to the water sources hence an increase in the management cost of the water resources. Therefore, the paper review on the quality of drinking water in Malawi challenges facing the quality of the water, water quality rating with reference to water quality index (WQI) and hence the treatment of the drinking water and suggestion of a sustainable way of solving the water quality depletion.

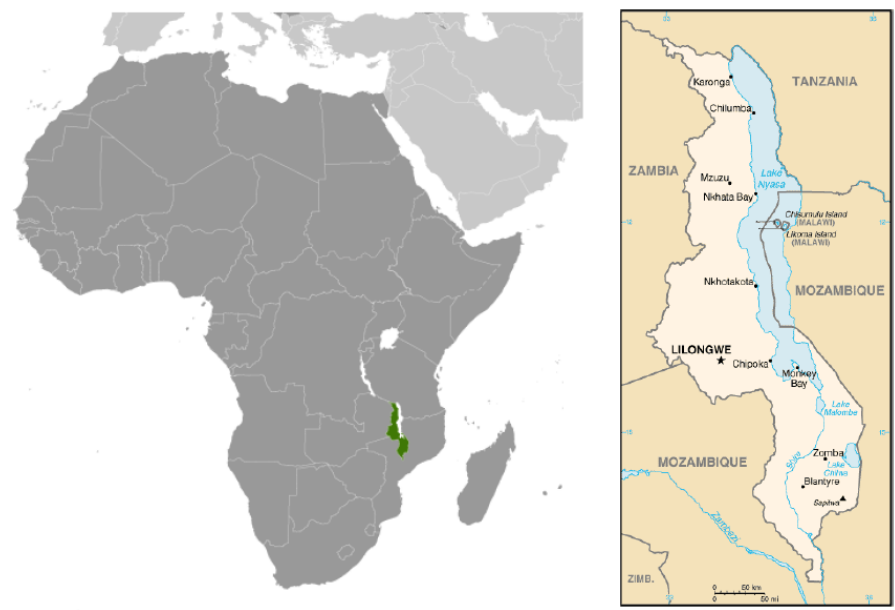

Figure 1 The location of Malawi on the African map. Source: The World Factbook (2012)

\subsection{Challenges in Drinking Water Quality in Malawi}

Malawi, a landlocked nation in Africa's southern region, is the region's smallest but most densely populated country, with approximately 18 million people, up nearly 5 million in the last decade. Malawi is a developing country, with more than half of the population living below the national poverty line (Back, Rivett et al. 2018). Malawi experiences a great challenge in the water sector, where about $75 \%$ of the population has access to freshwater. However, according to World Health Organization (WHO) Report, 2015 about $67 \%$ record of available portable and safe drinking water in Malawi country (Mkwate, Chidya et al. 2017), but still water supply and quality remain to be a major challenge since the majority of the people depend on the groundwater for drinking. Moreover, in the small community particularly in the rural regions the water supply is not closely monitored by the sector in charge of the water. Most developing countries face major problems concerning both the water quantity and quality which are severe as compared to developed regions (K'oreje, Vergeynst et al. 2016) leading to a shortage of clean drinking water in developing countries due to high demand and increased population. The water resources in developing regions are facing high challenges and pressure from different pollution sources (Manda, Chidya et al. 2016). Furthermore, a large population worldwide mostly rely on unprotected water resources such as streams, shallow wells, boreholes, lakes and rivers for domestic water consumption with inadequate sanitation and hygiene that has led to million 
people deaths and about $80 \%$ of illnesses in third-world countries according to WHO 2012 (Palamuleni 2002, Msilimba and Wanda 2013, Mkwate, Chidya et al. 2017). The pit latrines used in developing countries pose great risks to residence due to poorly understood threat of microbiological and chemical quality of the ground water sources (Back, Rivett et al. 2018). Additionally, ground water contamination is further examined by the rise of nitrogen species (ammonium and nitrates), faecal and total coliform, virus detection, total dissolved solids (TDS), sodium, sulphates and chloride due to closeness to latrines.

Malawi is one of the countries facing water scarcity, and serious water pollution challenges because of unsafe garbage collection, high levels of microorganisms and pathogens, salinity, and improper wastewater management and inadequate sanitation services in both rural and urban regions. The problem is becoming a threat to the living standards of people living in the regions. Water quality is limited for a considerable number of people living in rural areas and low-income populations (Ward, Lapworth et al. 2020). Long distances are traveled by the residents in the rural region in Malawi in search of water, which they get it from shallow wells, boreholes, and river, and consumed raw or untreated (Mkwate, Chidya et al. 2017). The untreated water contains high pathogenic microorganisms causing diseases, from the industrial wastes and wastewater leading to a high concentration of toxic organic substances in the water. Increased difficulty and costs in the treatment and distribution of clean water, led to water scarcity, poor water quality, and restrictions on the production of water supplies, hence, worsened further the quality of services (Kalulu and Hoko 2010). However, various approaches to limiting water usage must be used to tackle the water pollution issue.

Water resource pollution is the main issue to water quality depletion by the direct discharge of wastewater to water sources, such example of the Luwinga and Lunyangwa Rivers at Mzuzu city in Malawi were highly polluted by industrial waste and sewage from the broken pipes industries according to (Ngoma, Hoko et al. 2020). Moreover, the pollution of the water also caused by human activities such as deforestation, urbanization and agriculture contribute to poor water quality especially the surface water. Furthermore, water contamination can also be caused by poor storage and transportation methods. Concurrently, the depletion of water quality by agricultural activities is recorded as a worldwide problem and the quality of particularly the surface water can also be altered by weathering of rocks and precipitation as stated by (Chidya, Sajidu et al. 2011). Also industrial solid waste and chemical disposal, sewage and household wastewater mainly in the urban areas result in water contamination (Chidya, Sajidu et al. 2011). Above all, the most challenging part in Malawi for adequate water quality monitoring is insufficient administrative and technical management of water systems, insufficient technical capacity for water quality identification, lack of data sharing where no official ministry of the government body in charge of monitoring water quality in Malawi and coordination among the water ministries and surveillance of water quality laws and lack of skill in water analysis, insufficient staff in the water sector and scarce financial resources. In rural areas, the ability to track and control the water quality is affected by seasonal changes and constrained by a lack of financial resources to properly manage drinking water (Kayser, Amjad et al. 2015). These challenges are to be addressed by the water board and the governance to provide adequate room to residents in accessing pure clean water mostly to low-income and rural regions.
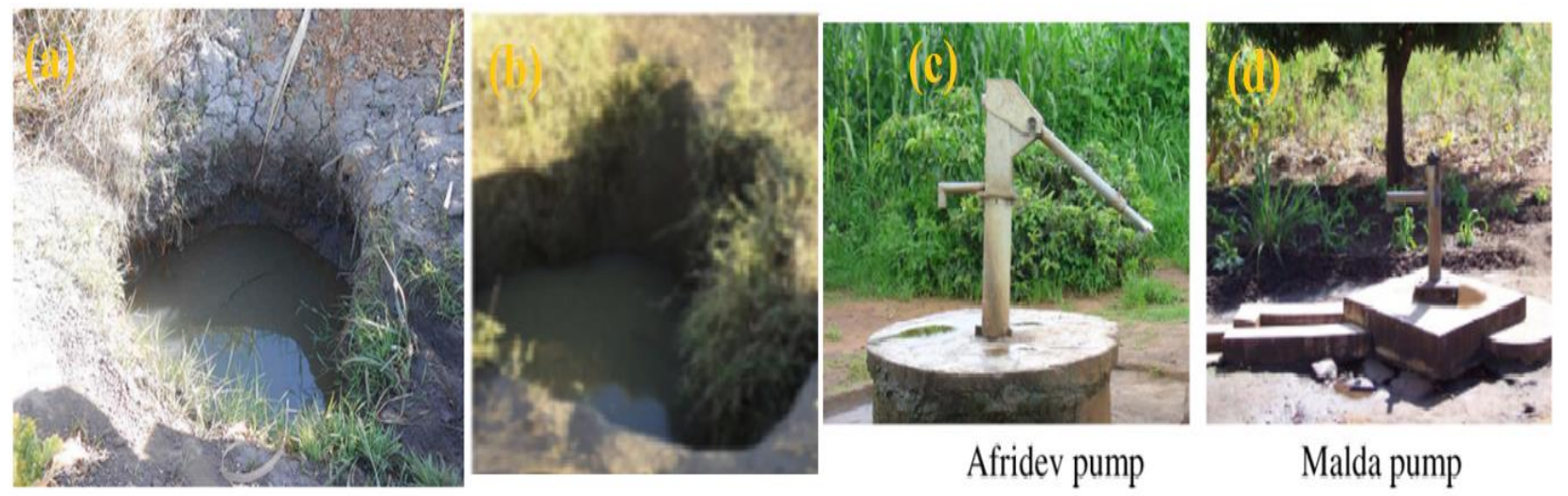

Figure 2 Surface water source (a), unprotected shallow well (b), borehole (c) and (d).

Source (Pritchard, Mkandawire et al. 2008, Mkwate, Chidya et al. 2017, Smiley 2017)

\subsection{Pollution status of drinking water in Malawi}

Groundwater provides about $25 \%$ to $40 \%$ of the world's drinking water (Monjerezi and Ngongondo 2012). Groundwater resources such as deep wells, boreholes, shallow wells, natural lakes, springs, and rivers provide for drinking water in Africa (Manda, Chidya et al. 2016, Smiley 2017, Lapworth, MacDonald et al. 2020). Furthermore, the boreholes equipped with handpump are mostly used for the access of the groundwater particularly in rural areas and the water is used in cooking and drinking without treatment. The developing countries, a large population consumes contaminated water by industrial discharge, chemicals used in the agricultural sector, municipal waste and wastewater leading to high infectious waterborne diseases (Megersa, Beyene et al. 2014, Smiley 2017). In Malawi, common water sources for domestic use are the groundwater such as the shallow well used most in rural areas (Msilimba and Wanda 2013, Nyirenda, Mapoma et al. 2015). Therefore, the determination of water quality from the protected and unprotected water sources is an important aspect that protects a country from waterborne illnesses and deaths. However, the level of water quality is determined in terms of standards set by the country or by WHO for drinking water. Similarly, experimental analysis was conducted in Malawi laboratories and several physicochemical parameters were analyzed for the determination of the quality of available water sources used 
for drinking. The analysis conducted in Mudi and Nasolo streams in Malawi country were highly polluted and recorded high concentrations of metals caused by the discharge of the wastewater from the nearby industries directly to the streams used by the residents for drinking (Sajidu, Masamba et al. 2007). The metals such as copper and nickel recorded high concentration values above WHO guidelines for drinking water in the streams due to the broken sewer line from the industries and the wastewater finds its way to the nearby water sources. Moreover, the sulfates and nitrates were within the required limit for drinking water of $250 \mathrm{mg} / \mathrm{L}$ and $50 \mathrm{mg} / \mathrm{L}$ respectively for WHO standards.

A study by (Pritchard, Mkandawire et al. 2007), also conducted another analysis in a different region of Malawi country (Chiradzulu, Blantyre and Mulanje) and recorded concentration level of parameters such as turbidity and $\mathrm{pH}$ of the water of the shallow well and obtained concentration above the set standards by WHO and Malawi Bureau of Standards (MBS) while the electrical conductivity (EC) concentration and TDS were within the set limits due to the dilutions of the rains. A study by (Pritchard, Mkandawire et al. 2008), also analyzed the physicochemical parameters of the water of the shallow well in the Southern District of Malawi country where the TDS, $\mathrm{pH}$, turbidity and EC levels of concentration were evaluated. The obtained results of the study indicated a high level of contaminants such as TDS, turbidity and EC above the allowable limits by WHO and MBS. Moreover, the recorded results of the shallow wells showed poor water quality for the microbiological contamination and most of the shallow well tested failed to attain the allowable limits by MBS and WHO for the zero coliforms. The total suspended solids (TSS) according to (Mkandawire and Banda 2009), is not supposed to be contained in the drinking water, but the analysis conducted in one of the wells of Mtopwa in Malawi recorded a high-value range above WHO standards for drinking water, this was caused by the discharge of wastewater to the receiving water bodies. The turbidity results of the shallow well water recorded the value range above the set limits by the MBS and WHO standards of 25 NTU and 5 NTU respectively.

The experimental study by (Manda, Chidya et al. 2016), analyzed the parameters such as turbidity, TDS, water hardness, water temperature, alkalinity, $\mathrm{pH}$ with also further contaminants such as nitrates, phosphates, chlorine, sulfates among other metals (Table 1) and the results compared to the MBS (2005) and WHO (2008) standards (Table 4). The test was conducted among the raw water to the water treatment plants in Malawi, where the Liwonde water treatment plant recorded high water turbidity of about 26.77 \pm 7.56 NTU, this was attributable to the anthropogenic activities in the surrounding areas due to livestock rearing, deforestation, and unlawful dumping of household garbage. The Zomba water treatment plant (ZWTP) treating water from Mulunguzi Dam also recorded a turbidity level of 3.17 $\pm 3.03 \mathrm{NTU}$ and the Chikwawa water treatment (CWTP) plant treating borehole water and recorded turbidity of $0.49 \pm 0.89$ NTU from the raw water. Other water treatment plants in Malawi; Liwonde water treatment plant (LWTP), Mulanje water treatment plant (MJWTP) and Mangochi water treatment plant (MHWTP) were also assessed their performance in treating water for use in drinking and irrigation. The analysis results for the water treatment plants in Malawi are as per (Tables 1) and most of the parameters are within the allowable standards for drinking water in Malawi.

\begin{tabular}{|c|c|c|c|c|c|c|c|c|}
\hline \multirow[t]{2}{*}{ Sampling point } & \multicolumn{5}{|c|}{ Parameter (Mean \pm SD) } & \multirow[b]{2}{*}{$\begin{array}{l}\text { Hardness } \\
(\mathrm{mg} / \mathrm{L})\end{array}$} & \multirow[b]{2}{*}{$\begin{array}{l}\text { Alkalinity } \\
\text { (mg/L) }\end{array}$} & \multirow[b]{2}{*}{$\begin{array}{l}\text { Temperature } \\
\left({ }^{\circ} \mathrm{C}\right)\end{array}$} \\
\hline & $\begin{array}{l}\text { Turbidity } \\
\text { (NTU) }\end{array}$ & $\mathrm{NO}_{3}^{-}$ & & $\mathrm{pH}$ & TDS (mg/L) & & & \\
\hline Mulunguzi Dam (ZWTP) & $3.17 \pm 3.03$ & $\begin{array}{l}0.64 \\
0.02\end{array}$ & \pm & $7.13 \pm 0.33$ & $11.3 \pm 0.93$ & $20.6 \pm 0.33$ & $19.48 \pm 2.13$ & $22.5 \pm 2.01$ \\
\hline $\begin{array}{l}\text { Namichira River at intake } \\
\text { (MJWTP) }\end{array}$ & $1.69 \pm 1.60$ & $\begin{array}{l}0.90 \\
0.01\end{array}$ & \pm & $6.79 \pm 0.42$ & $\begin{array}{l}12.10 \quad \pm \\
0.04\end{array}$ & $28.4 \pm 0.83$ & $19.16 \pm 2.75$ & $23.6 \pm 1.18$ \\
\hline $\begin{array}{l}\text { Muloza River at intake } \\
\text { (MJWTP) }\end{array}$ & $1.58 \pm 1.52$ & $\begin{array}{l}0.89 \\
0.19\end{array}$ & \pm & $7.20 \pm 0.26$ & $7.65 \pm 0.13$ & $27.9 \pm 0.51$ & $29.19 \pm 2.40$ & $23.4 \pm 0.12$ \\
\hline $\begin{array}{l}\text { Shire River at Liwonde } \\
\text { (LWTP) }\end{array}$ & $26.77 \pm 7.56$ & $\begin{array}{l}0.95 \\
0.44\end{array}$ & \pm & $7.67 \pm 0.20$ & $129 \pm 1.00$ & $100.03 \pm 6.69$ & $139.16 \pm 5.10$ & $29.4 \pm 0.32$ \\
\hline $\begin{array}{l}\text { Shire River at Mangochi } \\
\text { (MHWTP) }\end{array}$ & $1.36 \pm 1.13$ & $\begin{array}{l}0.64 \\
0.05\end{array}$ & \pm & $7.47 \pm 0.12$ & $126 \pm 0.58$ & $98.28 \pm 6.57$ & $133.71 \pm 4.22$ & $28.9 \pm 0.24$ \\
\hline $\begin{array}{l}\text { Chikwawa borehole no. } 50 \\
\text { (CWTP) }\end{array}$ & $0.49 \pm 0.89$ & $\begin{array}{l}0.99 \\
0.02\end{array}$ & \pm & $8.05 \pm 0.40$ & $\begin{array}{l}483.67 \quad \pm \\
1.15\end{array}$ & $\begin{array}{l}201.96 \\
41.53\end{array}$ & $404.07 \pm 9.27$ & $30.2 \pm 0.21$ \\
\hline $\begin{array}{l}\text { Chikwawa borehole no. } 80 \\
\text { (CWTP) }\end{array}$ & $0.34 \pm 0.75$ & $\begin{array}{l}0.67 \\
0.06\end{array}$ & \pm & $8.09 \pm 0.75$ & $\begin{array}{l}695.33 \quad \pm \\
3.51\end{array}$ & $\begin{array}{l}399.01 \\
42.17\end{array}$ & $489.52 \pm 7.88$ & $30.4 \pm 0.32$ \\
\hline
\end{tabular}

Table 1 Average concentration of Turbidity, $\mathrm{pH}$, total dissolved solids, total hardness, total alkalinity and the temperature of raw water at the treatment plants

$\mathrm{BH}$; borehole

According to (Smiley 2017), analyzed the water quality from shallow wells in Malawi and the results depict a high concentration of faecal coliform and bacteria counts. The study further reveals from other literature that the results of the water quality testing from 
the shallow wells were unsuitable for human consumption with only about $50 \%$ of the wells that attained the drinking water standards of Malawi with $90 \%$ of the shallow well water above the allowable limits. The high polluted shallow wells were those close to sources of contamination such as the latrines, wastes disposal area and near the stagnant waters. Research by (Mkwate, Chidya et al. 2017) determined the quality of water used in Malawi from the shallow wells and boreholes making 11 different sources of water selected in the Balaka district. The water samples from the 11 water sources selected were analyzed for the test of the physicochemical parameters such as EC, TDS, chloride $\left(\mathrm{Cl}^{-}\right)$, iron $(\mathrm{Fe})$, nitrates $\left(\mathrm{NO}_{3}{ }^{-}\right)$, sodium $(\mathrm{Na})$, potassium $(\mathrm{K})$, turbidity and $\mathrm{pH}($ figure 3 and 4$)$. The results were compared to WHO (2011) and MBS (2005) guidelines for drinking water.
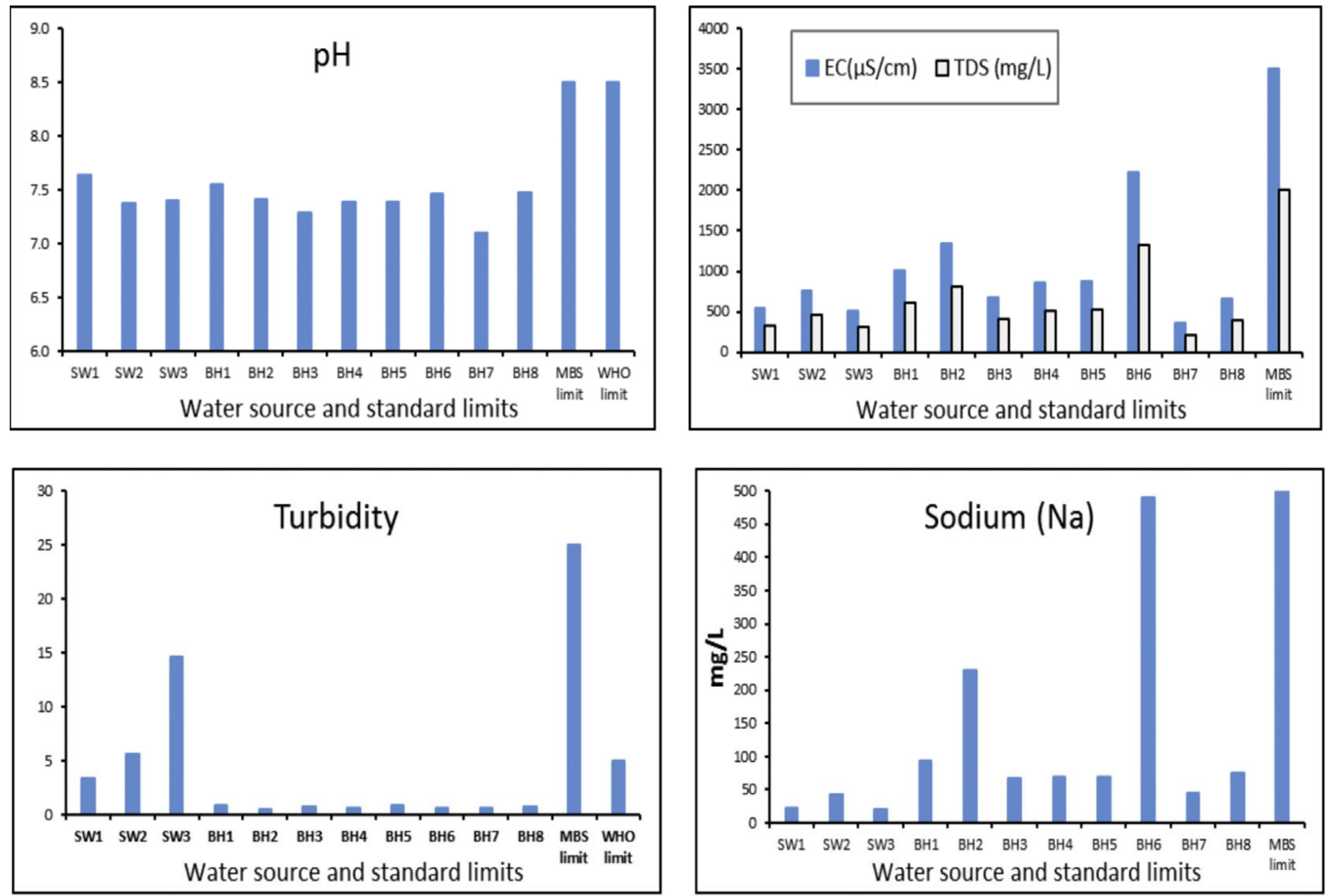

Figure 3 The EC, pH, turbidity, TDS and Na concentration in the water samples compared to water quality standards.

The $\mathrm{pH}$ mainly ranges between 6.0-8.5 and 6.5 - 8.5 for groundwater and surface water respectively. According to (Msilimba and Wanda 2013), pH is an essential parameter that determines the suitability of the water for a particular use. Moreover, the experimental analysis conducted for the sampled water from the shallow wells recorded the $\mathrm{pH}$ range of 4.9-6.3, the value range below the allowable limit by MBS 6.0-9.5 attributed to agricultural runoff. The analysis results by (Mkwate, Chidya et al. 2017) recorded a pH range of 7.107.55 from the borehole water and 7.38-7.64 in shallow wells and TDS value was within the recommended range by MBS (TDS 3,500 $\mu \mathrm{S} / \mathrm{cm}$ ) but above the set standards by WHO (TDS $=1000 \mathrm{mg} / \mathrm{L}$ ) for drinking water (figure 3). Turbidity of the two shallow wells recorded values above the WHO recommended standards for drinking water at 5 NTU but within the MBS allowable limits of 25 NTU (figure 3). The intrusion of runoff due to the absence of caps and casings, as well as soil contamination and re-suspension inside the well during water withdrawal, were accounted for the high turbidity levels found in the water. The sodium concentration levels in the water samples from all the 11 water sources ranged from $20-490 \mathrm{mg} / \mathrm{L}$ and were within the set limits by MBS 500mg/L, while two borehole water source recorded values above the allowable limits by WHO of $200 \mathrm{mg} / \mathrm{L}$ for drinking (figure 3).

The nitrates concentration in the drinking water ranged between 0 to $0.16 \mathrm{mg} / \mathrm{L}$ the value below the allowable limits by WHO at $50 \mathrm{mg} / \mathrm{L}$ and $45 \mathrm{mg} / \mathrm{L}$ by MBS. High bacteria counts were recorded in boreholes and shallow wells water samples analyzed and were above the WHO acceptable level of $0 \mathrm{cfu} / 100 \mathrm{~mL}$ and MBS $50 \mathrm{cfu} / 100 \mathrm{~mL}$ in boreholes and $0 \mathrm{cfu} / 100 \mathrm{~mL}$ in shallow wells for drinking water (figure 4). This may be due to runoff, open defecation, the closeness of the water sources to sanitary services and animal faecal waste discharge into water bodies. Malawi water is highly contaminated and is being consumed by the residents without treatment. The highly contaminated shallow wells recorded a high concentration of faecal bacteria and other pollutants which resulted in about $50 \%$ of illnesses in the country. Generally, the water analyzed recorded the quality that required treatment before consumption due to the high concentration of faecal coliform contamination. 


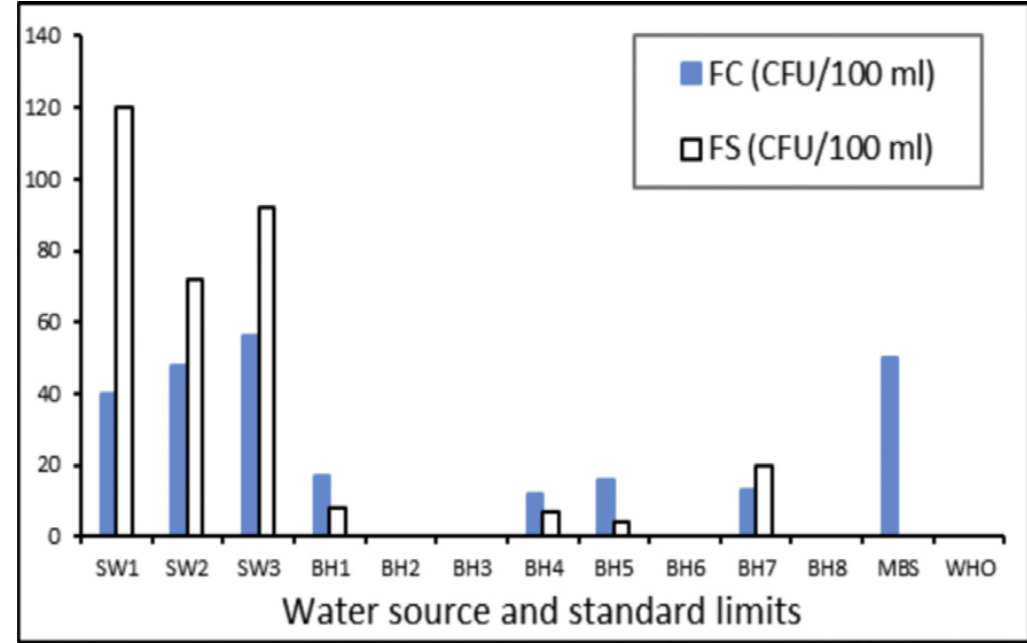

Figure 4 Microbiological characteristics (faecal streptococcus (FS) and faecal coliform (FC) bacteria) of the water sources compared to standards.

Table 2 Water source characteristics in different study areas of Malawi country. Source: (Mkwate, Chidya et al. 2017)

\begin{tabular}{lll}
\hline Name of location & Source & Features of water sources \\
\hline Njerenje & SW1 & Unprotected shallow well: water unreliable and not clean \\
Yasini & SW2 & Unprotected shallow well: water unreliable and not clean \\
Mussa & SW3 & Unprotected shallow well: water unreliable and not clean \\
Njerenje School & $\mathrm{BH} 1$ & Borehole water (IPBH0007): water clean and reliable \\
Jonasi & $\mathrm{BH} 2$ & Borehole water (IPBH0232): water reliable and partially clean \\
Phimbi Post Agency & $\mathrm{BH} 3$ & Borehole water (IPBH0227): water reliable but not clean \\
Phimbi Village & $\mathrm{BH} 4$ & Borehole water (IPBH0225): water reliable and partially clean \\
Matipani & $\mathrm{BH} 5$ & Borehole water (IPBH0224): water reliable and clean \\
Naweta & $\mathrm{BH} 6$ & Borehole water (IPBH0223): water reliable and partially clean \\
Kapalamula & $\mathrm{BH7}$ & Borehole water (IPBH0222): water unreliable and not clean \\
Jiya & $\mathrm{BH} 8$ & Borehole water (IPBH291): water unreliable and not clean \\
\hline
\end{tabular}

BH: Borehole; UNP SW: Unprotected shallow well

Table 3 Results on the risk-to-health classification of the water sources in terms of faecal coliform (FC) compared to standards

\begin{tabular}{|c|c|c|}
\hline FC Count $/ 100 m L$ & $\begin{array}{l}\text { Risk Category and recommendation on } \\
\text { the water source }\end{array}$ & $\begin{array}{l}\text { Category of the water sources }(n=11) \\
\text { understudy }\end{array}$ \\
\hline 0 & $\begin{array}{l}\text { In conformity with WHO guidelines } \\
\text { (may be consumed as it is) }\end{array}$ & (36\%) BH2, BH3, BH6, BH8 \\
\hline $1-10$ & $\begin{array}{l}\text { Low risk (Treated, if possible, but may } \\
\text { be consumed as it is) }\end{array}$ & nil \\
\hline $11-100$ & $\begin{array}{l}\text { Intermediate risk (Must be treated } \\
\text { before consumption) }\end{array}$ & (64\%) BH1, BH4, BH5, BH7, SW1, SW2, sW3 \\
\hline $101-1000$ & $\begin{array}{l}\text { High risk (Rejected or must be treated } \\
\text { thoroughly) }\end{array}$ & nil \\
\hline$>1000$ & $\begin{array}{l}\text { Very high risk (Rejected or must be } \\
\text { treated thoroughly) }\end{array}$ & nil \\
\hline
\end{tabular}

CAWST Training Manual (2009) and WHO (2011) 
Table 4 Physicochemical analysis of groundwater sources and comparison with Malawi drinking water guidelines

\begin{tabular}{ll}
\hline Parameter & $\begin{array}{l}\text { Malawi Standards } \\
(\mathrm{mg} / \mathrm{L})\end{array}$ \\
\hline Physical parameters & \\
Temperature ( $\left.{ }^{\circ} \mathrm{C}\right)$ & NA \\
TDS $(\mathrm{mg} / \mathrm{L})$ & 1000 \\
pH & $6.5-8.5$ \\
Major ions & \\
Bicarbonate (mg/L) & NA \\
Chloride (mg/L) & 600 \\
Fluoride (mg/L) & 2.0 \\
Nitrate (mg/L) & 100 \\
Phosphates (mg/L) & NA \\
Sulphate (mg/L) & 400 \\
Aluminum (mg/L) & 0.20 \\
Copper (mg/L) & 2.0 \\
Calcium & 200 \\
Iron (mg/L) & 1.0 \\
Magnesium (mg/L) & 150 \\
Manganese (mg/L) & 2.0 \\
Potassium (mg/L) & NA \\
Sodium (mg/L) & 200 \\
Zinc (mg/L) & 15 \\
Trace metals & \\
Arsenic (mg/L) & 50 \\
Cadmium (mg/L) & 10 \\
Lead (mg/L) & 50 \\
Selenium (mg/L) & 2.6 \\
\hline
\end{tabular}

\subsection{Water Quality Index (WQI) for Water Resources in Malawi}

Different methods have been proposed for water quality assessment and evaluated in terms of the chemical, physical, and biological nature of water concerning natural quality, human effects and intended uses e.g., in drinking and irrigation (Wanda, Gulula et al. 2012). However, the selected effective water quality detection methods highlighted are the salinity hazard (EC), Sodium Adsorption Ratio (SAR), Water Quality Index (WQI), Residual Sodium Carbonate (RSC) and total hardness (TH) (Monjerezi and Ngongondo 2012). Moreover, the effects of these methods of determining water quality offer valuable information to local policymakers who are responsible for maintaining essential fresh groundwater resources and allocating accessible supplies. Additionally, the water quality index (WQI) is chosen as a key method for determining water quality for domestic use as well as determining whether the overall effect of quality of water parameters poses a risk to different water uses such as drinking water sources (Nyirenda, Mapoma et al. 2015, Zhang, Zhang et al. 2020). The Water Quality Index (WQI) has been shown to provide valuable information to water resource managers since is believe to be an efficient useful and reliable method for communicating and evaluating the information on the overall quality of water (Mapoma, Xie et al. 2017). According to (Wanda, Gulula et al. 2012), higher values of the WQI indicate better quality of the water and lower values show poor quality water. However, the computed WQI values are classified into five classes as water unsuitable for drinking (WQI > 300), very poor water $(200<\mathrm{WQI}<300)$, poor water $(100<\mathrm{WQI}<200)$, good water $(50<\mathrm{WQI}<100)$ and excellent water (WQI < 50). A study by (Monjerezi and Ngongondo 2012), conducted research and random selection of the shallow wells and boreholes as the mainly used water resources in developing countries particularly in Chikwawa district in Malawi, and parameters such as $\mathrm{pH}$, TDS, EC, temperature chloride, nitrates, sodium and others were analyzed. The indicators of the groundwater quality were calculated to determine the suitability of the groundwater resources for domestic purposes. The majority of the groundwater was graded as mildly hard to very hard in terms of TH. In terms of the salinity the groundwater recorded high concentration indication of bad quality water due to mineralization in the analyzed samples from the borehole and shallow well. Study by (Msilimba and Wanda 2013), analysed shallow well water quality at Mzuzu City in Malawi and the analysis recorded high faecal coliform ranging from 129-920 cfu/100 ml for about $96.3 \%$ of the sample undertaken, the concentration was higher than the acceptable limits by WHO 2011 and MBS 2005. The WQI recorded a value range of 50.16-66.04\% with a medium WQ rating for all the samples analysed. The 100\% of the sample sites investigated were observed to be unsafe for human consumption without treatment since the water was slightly polluted.

A study by (Mapoma, Xie et al. 2017), analyzed groundwater samples from borehole water sources to ascertain the water quality of Karonga District in Malawi. Laboratory analyses were conducted and parameters such as potassium, sodium, calcium, magnesium, chloride, nitrates, sulfates among others were examined their concentration level in the water. The analysis was conducted to determine 
the suitability of the water for human consumption such as drinking purposes by comparing the water quality with allowable limits standards by WHO for drinking water and the WQI values were also analyzed. The study record poor water quality for drinking in most of the samples analyzed, $36 \%$ very poor and $16 \%$ of the water was unsuitable for drinking. According to (Wanda, Gulula et al. 2012), sampled tap water to determine the quality level of the water parameters for domestic use. Moreover, the samples analyzed in the study recorded WQI below 100. Besides, the raw water from the main water treatment plant intake before the treatment and distribution to water pipes, had a WQI of 62.67 percent, which is considered a medium or average indicator of water contamination, making it unsafe for direct human use without treatment. The rating of the parameters for the treated water recorded nitrates with a WQI ranging from 52.06-86.94 and water quality rating of 69.77, while the other parameters recorded good to excellent water quality ratings for example the TDS, EC, total hardness and sulfates recorded excellent water quality rating of 96.67, 97, 95.70 and 97.87 respectively. More of the parameters such as calcium, magnesium, turbidity, $\mathrm{pH}$ and chlorides recorded very good water quality ratings of 90.32, 92.87, 92.4, 80.21 and 93.02 respectively. However, the analysis results of the study show that the quality of the water particularly in the rating of the nitrates require improvement by introducing some more conventional and advanced water treatment methods. Moreover, WQI ranging from 80.28 to $88.80 \%$ was obtained as good water quality for about $91.67 \%$ sampled sites undertaken and $8.33 \%$ of the sampled sites recorded WQI of $90.07 \%$ classified as water with very good quality rating. Therefore, the treated water registered minimal pollution levels that required minimal treatment works prior to human consumption.

\subsection{Drinking Water Treatment Techniques}

Water purification for drinking and other household use in Malawi is by use of chemicals and they are always unavailable due to insufficient funding projects for the provision of the chemicals to the rural residents. The objective of treating drinking water is to make it suitable for consumption and free from pollution of any kind (Manda, Chidya et al. 2016). Moreover, the water treatment methods are categorized as physical, chemical, biological, and mechanical and they indicate the level of pollution of the water for potable water quality for drinking and suitable for public use. Furthermore, the naturally occurring products were previously used in the purification of drinking water there hence, advances in the use of filtration processes and disinfection by use of ozone and chlorine were employed. Also, the methods for treatment of water depend on the raw quality water, the regulations set for safeguarding the health of the people and the extent to which the water is polluted. The Joint Monitoring Programme (JMP), provided a record of Malawians using improved water sources which showed an increase from $42 \%$ in 1990 to $90 \%$ in 2015 (UNICEF \&WHO, 2015) (Smiley 2017). The JMP further projected a report of about 2.1 billion people having inadequate access to clean drinking water in Malawi (Cassivi, Tilley et al. 2021). To add to that, water demand in developing countries increases with an increase in population and mostly in the rural areas, there is unsafe water supply and inadequate sanitation facilities. The quality of the water used by the residents particularly in Malawi is poor and it requires close monitoring and development of treatment methods that are cost-effective and efficient in the removal of pollutants or purification of the water for prevention of outbreak of waterborne diseases and lower the high cases of deaths recorded yearly.

The commonly available water treatment techniques are at the household level used by low-income residents at the household water treatment (HWTs) methods such as boiling, solar disinfection or chlorination and filtration (Manda, Chidya et al. 2016, Mkwate, Chidya et al. 2017, Smiley 2017). The water treatment methods are of low cost, simple, and effective and are capable of reducing the number of illnesses by $47 \%$ in a country where applicable (Mkandawire and Banda 2009, Mkwate, Chidya et al. 2017). Moreover, the methods of household water treatment recover the microbial contaminated water quality but still, their effectiveness is very low in the removal of high turbid drinking water particularly from the unprotected water sources polluted mainly by wastewater discharged directly to the environment without proper management. Additionally, it is only about $5 \%$ (chlorination/water guard) and $25 \%$ (boiling) of the Malawian households that treat water for domestic consumption by use of the HWTs method (figure $\mathbf{5}$ X).
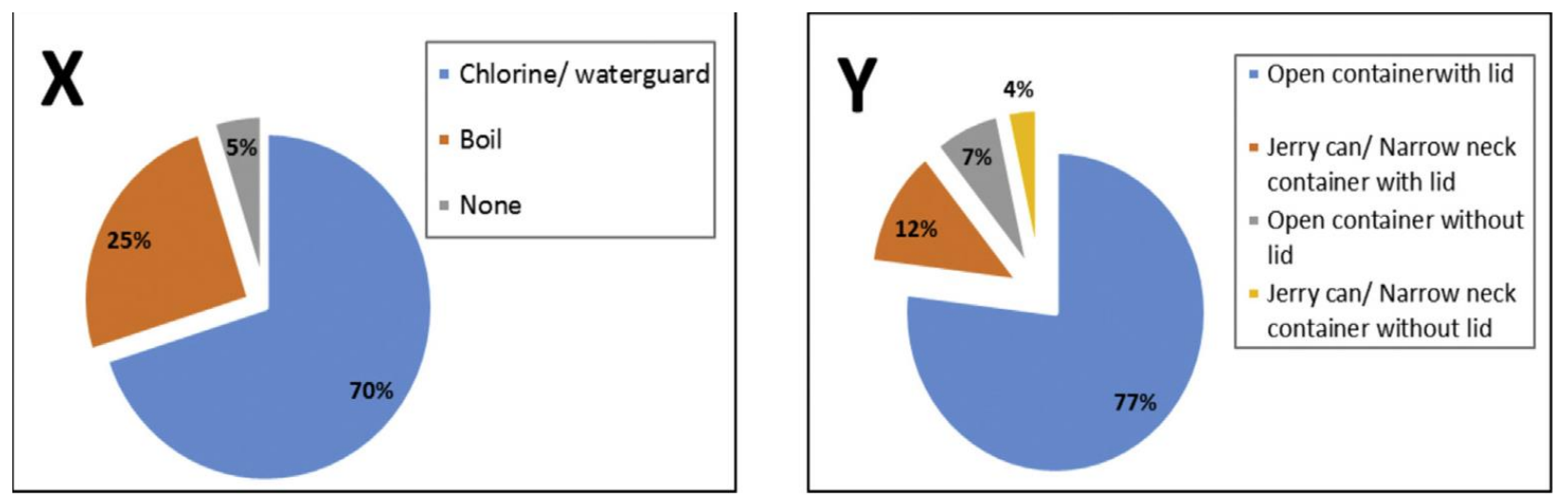

Figure 5 The households treating water by use of HWTs methods (X) and methods of water storage (Y) Source: (Mkwate, Chidya et al. 2017).

Furthermore, the municipal water sector uses coarse screens, clariflocculator, storage, disinfection, flocculator, plain sedimentation basins, clarifier, rapid filters, and removal of minerals and ions as the water treatment methods. Surface water sources and groundwater 
sources are used in Malawi by water treatment plants to determine the quality of the water for use by the residence in drinking, cooking and others (Manda, Chidya et al. 2016). Above all, no much-documented information in the literature about water treatment at the household level, the safety of water storage and water quality in the peri-urban and rural areas in Malawi (Mkwate, Chidya et al. 2017). In Malawi, there is several water treatments plant such as Mulanje, Zomba, Mangochi and Liwonde that treat water from the surface sources such as rivers while Chikwawa water treatment plant use groundwater sources. The Zomba water treatment plant has a design capacity of $18,000 \mathrm{~m}^{3} /$ day treating water from Mulunguzi Dam with the processes such as coagulation, flocculation, sedimentation, filtration and disinfection taking place (figure 6). Liwonde water treatment with a capacity of $2000 \mathrm{~m}^{3} / \mathrm{day}$ with the processes such as coagulation, sedimentation, pressure filtration and disinfection with chlorine and treats the water from Shire River (figure 6). Chikwawa water treatment plants are with a design capacity of $1200 \mathrm{~m}^{3} /$ day the only process used in this treatment plant is disinfection with chlorine and treats the groundwater. Mangochi water treatment plant uses pressure filtration and chlorination in treating raw water from Shire River and Mulanje water treatment plant has a design capacity of $1700 \mathrm{~m}^{3} /$ day uses manual chlorination process through the use of an improvised chlorinator and treats water from two rivers (Namichira and Mulonza).

An experimental study conducted in the Southern Region Water Board (SRWB) in Malawi that operates 23 urban centers water treatment plants, determined the efficacy of commercial coagulants used by the water treatment plants in the removal of pollutants in water such coagulants are algaefloc 19s, aluminum sulphate and sudfloc 3850 (Table 6). The performance of the treatment plants treating the water from sources such as groundwater, surface water and dams recorded very high efficiencies in reducing the turbidity by $99.0 \pm$ $0.05 \%$ of the water by the coagulation process at the Zomba water treatment plant, $98.6 \pm 0.04 \%$ turbidity reduction at Liwonde water treatment plant. The alum coagulants recorded low efficiency in the turbidity removal of the treated water from the treatment plants such as Mulanje, Mangochi and Chikwawa this was attributed to low water turbidity which is said to be difficult to treat due to few quantities of sediments generated to form dense and colloidal flocs (Table 5). The treated water from the water treatment plants registered water quality suitable for domestic use in cooking, drinking, and washing.

Table 5 Variance analysis for the coagulants (Alum, Sudfloc 3850 and Agaefloc)

\begin{tabular}{|c|c|c|c|c|c|c|}
\hline \multirow[t]{2}{*}{ Treatment plant } & \multicolumn{2}{|l|}{ Alum } & \multicolumn{2}{|l|}{ Sudfloc } & \multicolumn{2}{|l|}{ Algaefloc } \\
\hline & $\begin{array}{l}\text { Turbidity } \\
\text { Reduction } \\
\text { (Mean } \pm \text { SD) }\end{array}$ & $\begin{array}{l}\text { Optimum pH } \\
\text { (Mean } \pm \text { SD) }\end{array}$ & $\begin{array}{l}\text { Turbidity } \\
\text { Reduction } \\
\text { (Mean } \pm \text { SD) }\end{array}$ & $\begin{array}{l}\text { Optimum pH } \\
\text { (Mean } \pm \text { SD) }\end{array}$ & $\begin{array}{l}\text { Turbidity } \\
\text { Reduction } \\
\text { (Mean } \pm \text { SD) }\end{array}$ & $\begin{array}{l}\text { Optimum pH } \\
\text { (Mean } \pm \text { SD) }\end{array}$ \\
\hline Zomba & $99.0 \pm 0.05$ & $7.57 \pm 0.05$ & $19.6 \pm 0.02$ & $7.14 \pm 0.06$ & $20.5 \pm 0.02$ & $7.35 \pm 0.10$ \\
\hline Liwonde & $98.6 \pm 0.04$ & $7.45 \pm 0.01$ & $97.2 \pm 0.04$ & $7.80 \pm 0.02$ & $98.7 \pm 0.03$ & $7.77 \pm 0.06$ \\
\hline Mangochi & $13.0 \pm 0.02$ & $7.30 \pm 0.01$ & $98.4 \pm 0.06$ & $7.31 \pm 0.01$ & $97.5 \pm 0.05$ & $7.38 \pm 0.04$ \\
\hline Mulanje & $25.0 \pm 0.02$ & $7.28 \pm 0.01$ & $29.2 \pm 0.04$ & $7.37 \pm 0.04$ & $28.4 \pm 0.03$ & $7.47 \pm 0.08$ \\
\hline Chikwawa & $7.50 \pm 0.01$ & $8.21 \pm 0.08$ & $9.43 \pm 0.02$ & $8.30 \pm 0.10$ & $9.52 \pm 0.01$ & $8.30 \pm 0.06$ \\
\hline
\end{tabular}

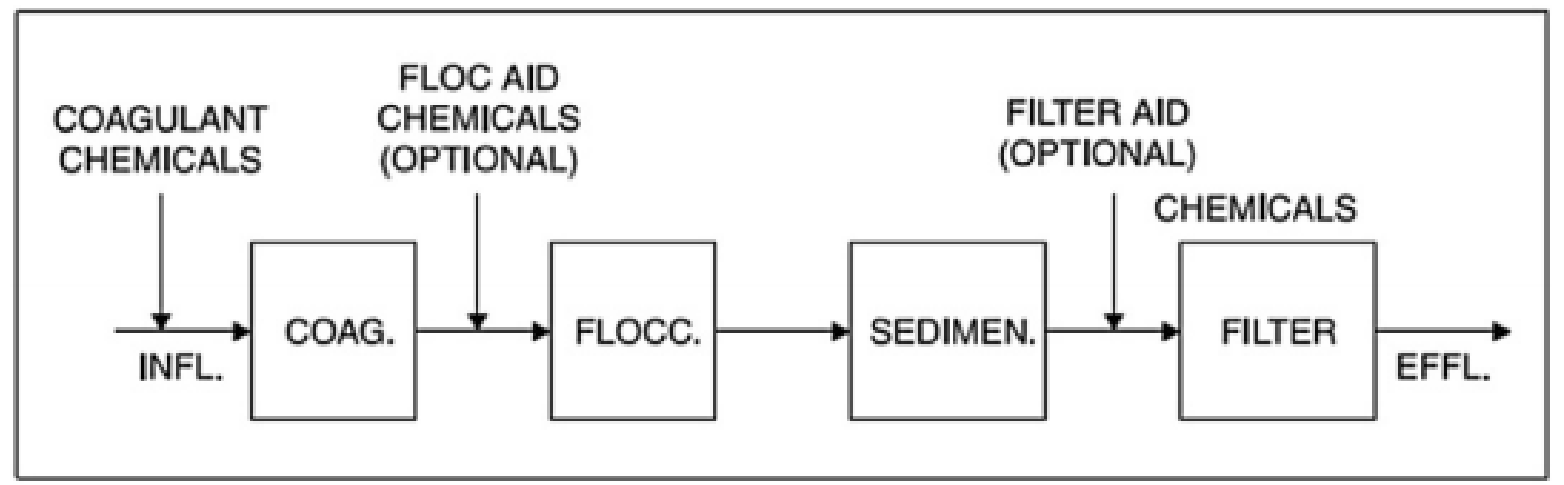

Figure 6 Schematic diagram of conventional filtration processes at Zomba and Liwonde water treatment plant. INFL-Influent, EFFL- Effluent, COAG- Coagulation, SEDIMEN- Sedimentation, FLOCC- Flocculation.

Source (Manda, Chidya et al. 2016)

\subsection{Administrative and technical management}

Malawi's National Water Policy outlines a vision of "water and sanitation for everyone, always " (Government of Malawi, 2005, p. 2), and the country has made efforts to improve water access. The Ministry of water development in Malawi is mainly concerned with water service provision, surveillance and water sector policy. However, the ministry manages the water services from five major water boards in the country such as Blantyre, Southern, Northern, Lilongwe and Central. In Malawi, a shortage of financial resources in district assemblies and water boards limits the maintenance and operating needs that can be handled, and unlawful water pipe tapping to take water reduces the billable water accessible in rural regions. According to financial statistics, from 1998 to 2006 , all five Water Boards 
made net losses from their activities (Kalulu and Hoko 2010). Officials from the Waterboard have indicated persistent resource constraints such as "availability of few vehicles for field visits, aging of the water pipes, and too few inspectors". "During droughts, vandalism is a concern, and pipes are destroyed to get water." (Kayser, Amjad et al. 2015). Moreover, the National Water Policy of Malawi was developed in 2005 and also the development of Integrated Water Resource Management (IWRM) is to improve people's lives by promoting sustainable water resource development, management, and use (Chidya, Sajidu et al. 2011).

Table 6 Laws and policies that govern drinking water quality in Malawi

\begin{tabular}{|c|c|c|}
\hline Water Resources Act & $\begin{array}{l}\text { 1969, amended in } \\
1996\end{array}$ & $\begin{array}{l}\text { Defines water rights, ownership, public water pollution, and } \\
\text { establishes the Water Resources Board as the body } \\
\text { responsible for managing water resources. }\end{array}$ \\
\hline Malawi Water Works Act & 1995 & $\begin{array}{l}\text { Establishes a legislative framework for the implementation } \\
\text { of an integrated water resources management policy by } \\
\text { defining the functions and responsibilities of agencies in the } \\
\text { sector, particularly water boards. The Water Boards are } \\
\text { governed by the provisions of this Act. }\end{array}$ \\
\hline Water Policy & 2005 & $\begin{array}{l}\text { Describes an integrated approach to water } \\
\text { management, establishes a centralized water management } \\
\text { system around catchment areas, as well as roles and duties } \\
\text { for water management. }\end{array}$ \\
\hline $\begin{array}{l}\text { Malawi Bureau } \\
\text { Standards }\end{array}$ & 2011 & $\begin{array}{l}\text { Specifies how water quality sampling procedures should be } \\
\text { carried out. }\end{array}$ \\
\hline
\end{tabular}

\section{CONCLUSION}

Water is an important resource for human consumption. Water is required safe and free from pollution of any kind. Therefore, the research found out that water contamination is a great challenge facing residents particularly those under low-income range and rural areas. Water contamination was observed mainly from wastewater being discharged directly to the environment with a high concentration of pollutants leading to the outbreak of waterborne diseases. The raw water is consumed without treatment due to poor sanitation and poor treatment techniques or no treatment of water. The commonly used drinking water sources are groundwater and surface water with a record of high concentration of the faecal coliform and bacteria counts above the acceptable limits by MBS and WHO while the home water treatment methods such as chlorination, boiling and filtering only reduces the microbial load in the water thus reducing cases of outbreak of cholera. Water sources such as the boreholes and shallow wells recorded a high concentration of turbidity above the allowable limits by WHO and MBS. The water treatment plants in Malawi, treated by coagulation showed a positive effect on the water pollutants. The $\mathrm{pH}$ range of the treated water was within the required standards for drinking water. The raw water analyzed in different studies indicated averaged water quality rating making the water unsuitable for human consumption without treatment. Most of the parameters in the analyzed water samples registered water quality ratings ranging from good to excellent. The water treatment plants recorded an overall water quality rating ranging from good to very good thus the water quality was suitable for consumption.

\subsection{Recommendation}

The study suggests that sophisticated treatment works to be implemented in order to improve the WQ rating of the nitrates and other pollutants of high concentration in water that impact the overall quality of the water. According to the review report, the water board should consider upgrading storage and onsite treatment systems to prevent having water quality vary significantly from the same source. The WQI should also be used to monitor and establish trends in the quality of water delivered. The findings indicated that there is a need to increase efforts in encouraging households to considerable apply onsite shallow well water purification operations for direct use.

\section{ACKNOWLEDGMENT}

Thanks to our mentor, Prof. Zhang Yongji and our research group for all kinds of support. We also thank Zulu Bernard for his comments and suggestions. All authors have read and agreed on the manuscript version to be published.

\section{REFERENCES}

[1] Back, J. O., et al. (2018). "Risk assessment to groundwater of pit latrine rural sanitation policy in developing country settings." Science of The Total Environment 613: 592-610. 
[2] Björklund, G. (2001). "Water management in developing countries-policy and priorities for EU development cooperation." SIWI report 12.

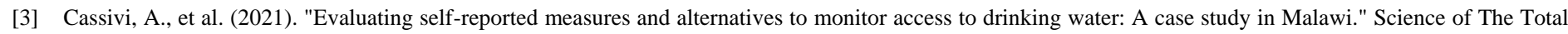
Environment 750: 141516.

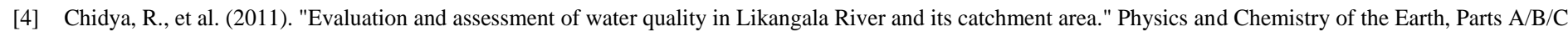
36(14-15): 865-871.

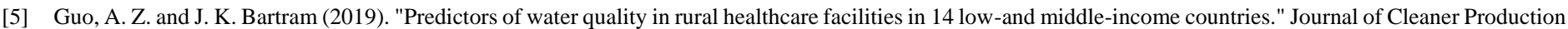
237: 117836

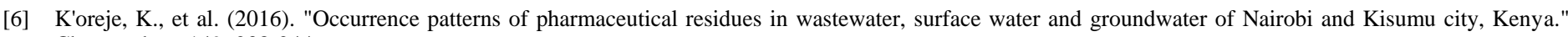
Chemosphere 149: 238-244.

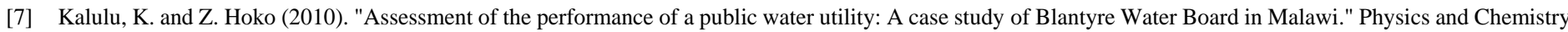
of the Earth, Parts A/B/C 35(13-14): 806-810.

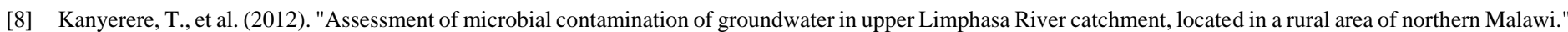
Water SA 38(4): 581-596.

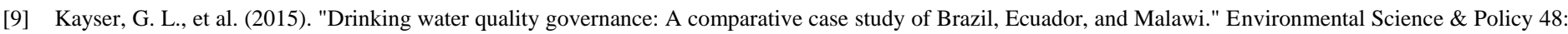
186-195.

[10] Lapworth, D., et al. (2020). "Drinking water quality from rural handpump-boreholes in Africa." Environmental Research Letters 15(6): 064020.

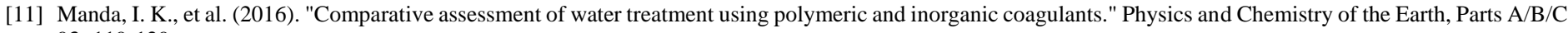
93: 119-129.

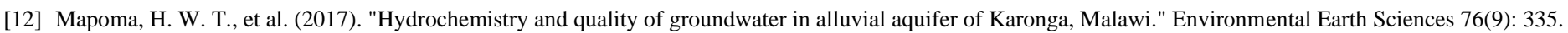

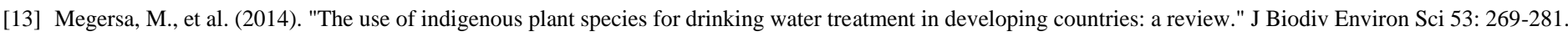

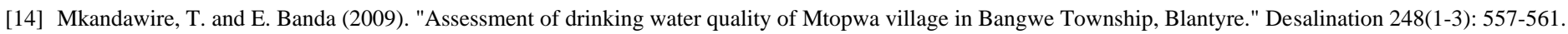

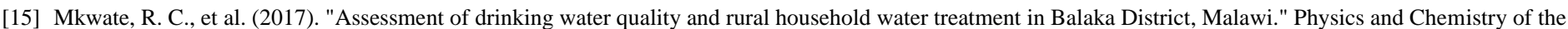
Earth, Parts A/B/C 100: 353-362.

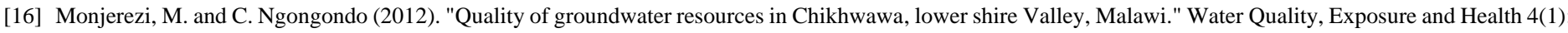
39-53.

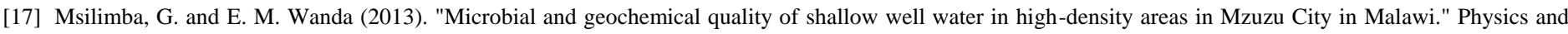
Chemistry of the Earth, Parts A/B/C 66: 173-180.

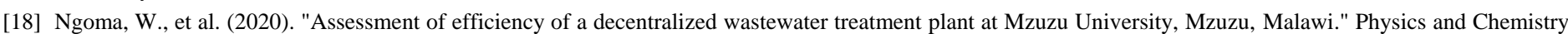
of the Earth, Parts A/B/C 118: 102903.

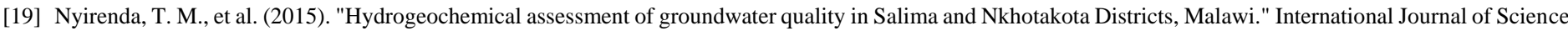
and Research 14: 1568-1576.

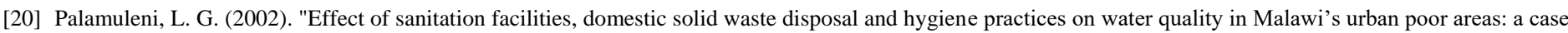
study of South Lunzu Township in the city of Blantyre." Physics and Chemistry of the Earth, Parts A/B/C 27(11-22): 845-850.

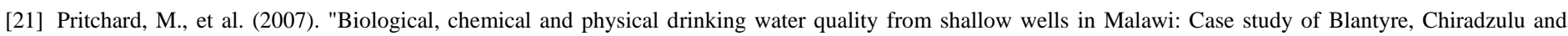
Mulanje." Physics and Chemistry of the Earth, Parts A/B/C 32(15-18): 1167-1177.

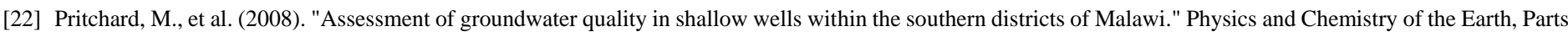
A/B/C 33(8-13): 812-823.

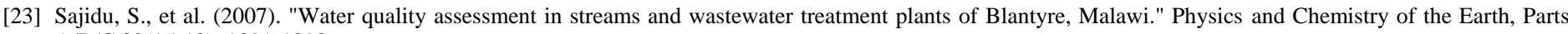
A/B/C 32(15-18): 1391-1398.

[24] Smiley, S. L. (2017). "Quality matters: incorporating water quality into water access monitoring in rural Malawi." Water International 42(5): 585-598.

[25] Tyagi, S., et al. (2013). "Water quality assessment in terms of water quality index." american Journal of water resources 1(3): 34-38.

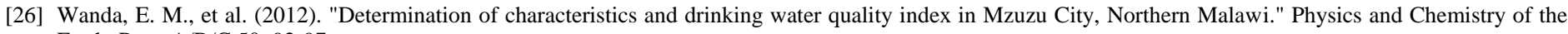
Earth, Parts A/B/C 50: 92-97.

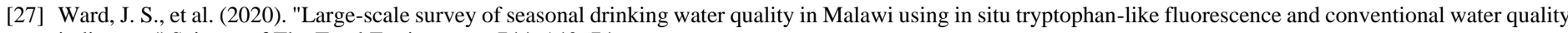
indicators." Science of The Total Environment 744: 140674.

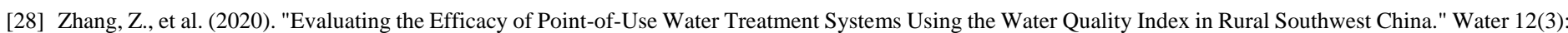
867.

\section{AUTHORS}

First Author - Mumba Mercy, BEng Bachelor of Civil Engineering, currently pursuing a Master of Environmental Science and Engineering at Tongji University in Shanghai China. UNEP-TONGJI Institute of Environmental Sciences and Sustainable Development (IESD) Tongji University, College of Environmental Science and Engineering, Tongji University, Shanghai 200092, China. Email: mumba_mercy@yahoo.com

Second Author - Kilingo Flory Mkangombe, BSC Bachelor of Education Science, currently pursuing a Master of Environmental Science and Engineering at Tongji University in Shanghai China. UNEP-TONGJI Institute of Environmental Sciences and Sustainable Development (IESD) Tongji University, College of Environmental Science and Engineering, Tongji University, Shanghai 200092, China. Email: florymkangombe@ gmail.com

Third Author - Prof. Zhang Yongji, Theory and technology of drinking water membrane bioreactor technology, New safe disinfection technology for drinking water, Water supply network water quality assurance theory and technology; State Key Laboratory of Pollution control and Resource Reuse, College of Environment Science and Engineering, Tongji University No 588 Miyun Rd. Shanghai, P.R. China,200092. Tel+8613701815538, Email: zhangyongji@ tongji.edu.cn 
Correspondence Author - Prof. Zhang Yongji, Email: zhangyongji@tongji.edu.cn, contact number Tel: +8613701815538 